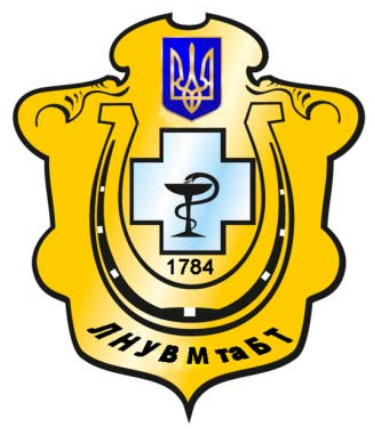

Науковий вісник Львівського національного університету ветеринарної медицини та біотехнологій імені С.З. Гжицького

Scientific Messenger of Lviv National University of Veterinary Medicine and Biotechnologies named after S.Z. Gzhytskyj

doi:10.15421/nvlvet7151

ISSN 2413-5550 print

ISSN 2518-1327 online

http://nvlvet.com.ua/

UDC 636.084.52:636.087.72

\title{
Organic trace element complex for calves feeding
}

\author{
V.F. Radchikov, V.P. Tsai, V.K. Gurin, V.A. Lyundishev \\ labkrs@mail.ru, lion.vlad1959@mail.ru \\ RUE «Scientific and practical center of the National academy of sciences of Belarus for Animal husbandry», \\ Zhodino, the Republic of Belarus \\ EI «Belarusian State Agrarian Technical University», Minsk, the Republic of Belarus
}

Trace elements are commonly used in the form of inorganic salts poorly digested by ruminants due rumen microflora, which transits its greater part into indigestible and insoluble form. Trace elements in the form of chelates are supplied with amino acids and peptides, and used by the body much more efficiently. Inclusion of organic trace element complex (OMEK) in compound feed $K R-1$ in the amount of $10 \%$ of the existing standards for trace elements content in typical formulations for growing young cattle for meat has a positive impact on palatability of feeds, morphological and biochemical composition of blood and animals' performance, economic efficiency of calves fattening. Use of organic trace element complex in compound feeds KR-1 increases concentration of total protein in blood by $8-12 \%(P<0.05)$, reduces the amount of urea by $11-16 \%(P<0.05)$. Comparative analysis showed that animals in experimental group II used the feeds more efficiently. Metabolizable energy consumption per $1 \mathrm{~kg}$ of weight gain made $33.7 \mathrm{MJ}$ against $37.4 \mathrm{MJ}$ in the control group or by $9.9 \%$ lower, the same trend is established for digestible protein cost - by $10 \%$. Inclusion of OMEK in compound feed KR-1 for young cattle ensures average daily weight gain increase by $12.3 \%(P<0.05)$, decreased of feed cost per $1 \mathrm{~kg}$ of weight gain by $10 \%$. Use of organic trace element complex helps to decrease the cost price of weight gain, by $9.0 \%$ and obtain extra profit of $\$ 37.2$ USD per one animal during the experimental period.

Key words: energy, organic trace element complex, compound feed, diet, blood, weight gains, feed cost.

Citation:

Radchikov, V.F., Tsai, V.P., Gurin, V.K., Lyundishev, V.A. (2016). Organic trace element complex for calves feeding. Scientific Messenger LNUVMBT named after S.Z. Gzhytskyj, 18, 3(71), 225-227.

\section{Introduction}

Knowledge of the natural amount of trace elements in feeds and diets is a prerequisite for the organization of a balanced nutrition and obtaining high performance of animals (Radchikov et al., 2010; Suchkova et al., 2012; Kairov et al., 2014).

Belarus is a non-chernozemic area, where diets always lack such trace elements as $\mathrm{Zn}, \mathrm{Cu}, \mathrm{Co}$, I and $\mathrm{Mn}$. The biological role of these elements is essential not only to ensure high milk and meat performance, but also for animals' health and normal reproduction functions (Radchikov et al., 2014).

One of the tasks of scientific research in this direction is to increase the bio-availability of minerals. In recent years in animal husbandry, as a rule, inorganic forms are used to replenish the deficiency of trace elements. However it is determined that mineral salts are not completely digested in the gastrointestinal tract of animals.

Numerous researches conducted in our country and abroad prove a more efficient positive impact of organic form trace elements on animals' performance compared with inorganic (Radchikov et al., 2014).

Use of organic compounds increases absorption of $\mathrm{Zn}$, $\mathrm{Cu}, \mathrm{Mn}, \mathrm{Fe}$ and $\mathrm{Co}$, allows to control these trace elements more precisely and maintain productive and reproductive traits of animals, ensure increase of fat and protein content in milk, reduction of somatic cells, process of formation of the immune status and decrease of animals' diseases.

The aim of research was to study the efficiency of trace elements in organic form for feeding young cattle.

Research objectives. 1. To study feeds' nutrients intake.

2. To determine the biological and chemical composition of blood of experimental animals. 3. To determine the feed energy conversion into produce, average daily weight gains and cost-effectiveness of organic mineral complex (OMEK) use for calves feeding. 


\section{Material and methods}

Clinically healthy young cattle had been selected to achieve the objectives taking into account body weight, age, fatness and growth rate of calves.

In scientific and economic research the steers of the control group received compound feed $\mathrm{KR}-1$ with premix of standard formulation, milk, milk replacer, hay, silage, rolled corn grain; and young cattle of the II group - KR-1 feed with premix consisting of organic trace element complex in addition to the basic diet.

\section{Results and discussion}

Researches helped to determine that dry matter intake of experimental animals was at a level of 1.71-1.75 $\mathrm{kg} /$ day. Concentration of metabolizable energy in dry matter of diets in the II experimental group made 14.6 MJ against 14.7 - in the I control group. Crude protein in dry matter (DM) of diet in the control group made $24.5 \%$, in the experimental - 24.3. 14.1 grams of digestible protein came per $1 \mathrm{MJ}$ of metabolizable energy (MA) of diet in control and experimental groups. Concentration of easily digestible carbohydrates (starch and sugar) in the DM of diet in the I control group made $33.5 \%$ against $32.9 \%$ - in the II experimental group. The ratio of calcium and phosphorus in the diet of the I control group was at the level of $1.3: 1$, in the II experimental group $-1.31: 1$.

The use of trace element organic complex in compound feeds KR-1 increases total protein concentration in blood by $8-12 \%(\mathrm{P}<0.05)$, and decreases the amount of urea by $11-16 \%(\mathrm{P}<0.05)$.

The researches helped to determine positive effect of feeding calves with premix in composition of compound feed KR-1 during rearing from 10 to 75-days of age containing inorganic salts of elements, and with premix with the salts replaced by the organic form of iron, manganese, copper, cobalt and zinc on the body weight the average daily weight gains of calves (Table 1).

Table 1

Body weight and performance

\begin{tabular}{|c|c|c|}
\hline \multirow{2}{*}{ Index } & \multicolumn{2}{|c|}{ Group } \\
\hline & I & II \\
\hline Body weight at the beginning of experiment, $\mathrm{kg}$ & $42.5 \pm 0.6$ & $41.9 \pm 0.64$ \\
\hline Body weight at the end of experiment, $\mathrm{kg}$ & $86.3 \pm 1.05$ & $91.1 \pm 1.36$ \\
\hline Average daily weight gain, $g$ & $674 \pm 21.85$ & $757 \pm 18.46^{*}$ \\
\hline Increase of average daily weight gain, $\mathrm{g}$ & - & 83 \\
\hline Increase of average daily weight gain, $\%$ & - & 12.31 \\
\hline Extra weight gain from 1 animal per experiment, $\mathrm{kg}$ & - & 5.40 \\
\hline Feed cost per $1 \mathrm{~kg}$ of weight gain, feed units & 4.29 & 3.86 \\
\hline Decrease of feed cost, feed units & - & 0.43 \\
\hline$\%$ & - & 10.0 \\
\hline Metabolizable energy per $1 \mathrm{~kg}$ of weight gain, MJ & 37.4 & 33.7 \\
\hline Digestible protein per $1 \mathrm{~kg}$ of weight gain, $\mathrm{g}$ & 623.3 & 561.7 \\
\hline Extra attributable profit counted per 1 animals per experiment, USD & - & 37.2 \\
\hline
\end{tabular}

$* \mathrm{P}<0.05$

The final body weight at the end of the experiment differed between the groups in compliance with the intensity of calves growth. Thus, the highest increase of performance by $12.3 \%$ was observed in the II experimental group.

Data on efficiency of feed energy for weight gain indicate that in calves consuming compound feed KR-1 with chelate compounds of trace elements the deposit energy increased by $4.0 \%$ with respect to metabolizable energy. Calculated per $100 \mathrm{~kg}$ of body weight the deposit energy in the control group made $9.8 \mathrm{MJ}$, and in experimental $-11.1 \mathrm{MJ}$ or $13.3 \%$ higher, that ensured increase of coefficient of productive energy use from 0.55 to 0.64 and average daily weight gain by $12.3 \%$.

The use of organic trace element complex for feeding animals of experimental group allowed to decrease the prime cost of weight gain by $9.0 \%$ and obtain extra profit of \$37.2 USD per animal over the experimental period.

\section{Conclusion}

Thus, the use of organic trace element complex in compound feeds $\mathrm{KR}-1$ has a positive impact on morpho- logical and biochemical composition of blood, also increases the total protein concentration by $8-12 \%(\mathrm{P}$ $<0.05)$, and decreases the amount of urea by $11-16 \%$ (P $<0.05)$.

Inclusion of OMEK in the compound feed KR-1 for young cattle increases the average daily weight gains by $12.3 \%(\mathrm{P}<0.05)$, while reducing the feed cost per $1 \mathrm{~kg}$ of weight gain by $10 \%$.

The use of organic trace element complex allows to reduce the prime cost of weight gain depending on the age of young cattle by $9.0 \%$ and obtain extra profit of $\$ 37.2$ USD per animal during the experimental period.

\section{Perspectives of further researches.}

Researches are required on the use of OMEK for feeding older age young cattle. Also development of new mineral elements in organic form is very important.

\section{References}

Kairov, V.R., Kalagova, R.V., Karaeva Z.A., Tsugkieva, Z.R. (2014). Produktivnye i biohimicheskie pokazateli molodnjakakrupnogo rogatogo skota pri kompleksnom ispol'zovanii biologicheski aktivnyh do- 
bavok v kormlenii - Productive and biochemical indices of young cattle at complex use of biologically active additives in feeding. Izvestija Gorskogo Gosudarstvennogo Agrarnogo Universiteta - News of Gorki State Agrarian University. Vladikavkaz. 51(3), 86-93. Suchkova, I.V., Radchikov, V.F., Gurin, V.K., Yatsko, N.A., Bukas, V.V. (2012). Vlijanie skarmlivanija kombikorma $\mathrm{kr}-1 \mathrm{~s}$ selenom teljatam na konversiju jenergii racionov $\mathrm{v}$ produkciju - Effect of feeding calves with fodder KR-1 with selenium on diets energy conversion into produce. Uchenye zapiski uchrezhdenija obrazovanija «Vitebskaja ordena «Znak Pocheta» gosudarstvennaja akademija veterinarnoj mediciny» - Notes of EE «Vitebsk State Academy of Veterinary Medicine». 48(1), 299-303.

Radchikov, V.F., Gurin, V.K., Kononenko, S.I., Bukas, V.V., Lyundishev V.A. (2010). Effektivnost' ispol'zovanija razlichnyh doz selena $\mathrm{v}$ sostave kombikorma KR-2 dlja bychkov - Efficiency of different selenium doses in compound feed KR-2 for calves. Uchenye zapiski uchrezhdenija obrazovanija «Vitebskaja ordena «Znak Pocheta» gosudarstvennaja akademija veterinarnoj mediciny» - Scientific Notes of EE «Vitebsk State Academy of Veterinary Medicine». 46(1-2), 190-194.

Radchikov, V.F., Tsai, V.P., Kot, A.N., Kurtina, V.N., Pilyuk, N.V., Tsarenok, A.A., Yanochkin, I.V. (2014). Transformacija jenergii racionov bychkami v produkciju pri ispol'zovanii sapropelja - Transformation of energy in diets by calves into products using sapropel. Zootehnicheskaja nauka Belarusi - Zootechnical science of Belarus : scientific papers collection. Zhodino. 49(2), 148-158.

Radchikov, V.F., Yaroshevich, S.A., Budko, V.M., Lyundishev, V.A., Shareyko, N.A. (2014). Konversija jenergija racionov bychkami $\mathrm{V}$ produkciju pri skarmlivanii sapropelja - Diets energy conversion into produce by calves fed with sapropel. Zootehnichna nauka: istorija, problemi, perspektivi $=$ Zootichnical science: history, problems and prospects : materials of the IV International scientific and practical conference / Podolsk State Agrarian and Technical University. Kamenets-Podolskiy, Edition PP Zvoleyko D.G., 154-155.

Стаття надійшла до редакиії 1.10.2016 